\section{Postharvest Calcium Chloride Application and Moisture Barrier Influence on Peach Fruit Quality}

\author{
G. Lysiak ${ }^{1}$, W.J. Florkowski ${ }^{2,4}$, and S.E. Prussia ${ }^{3}$
}

ADDITIONAL INDEX WORDs. firmness, nondestructive test, destructive test, soluble solid content, titratable acidity, Prunus persica

Summary. Peaches (Prunus persica) were evaluated for storability after dipping in a $2 \%$ calcium chloride $\left(\mathrm{CaCl}_{2}\right)$ solution at $20^{\circ} \mathrm{C}$ for $30 \mathrm{~min}$ and storing them at $4{ }^{\circ} \mathrm{C}$ for 2 weeks in boxes uncovered or covered with polyethylene bags. Generally, there were significant improvements in storability resulting from the $\mathrm{CaCl}_{2}$ and the polyethylene barrier. The $\mathrm{CaCl}_{2}$ treatment improved firmness, largely maintained the soluble solids content, and increased the ratio of soluble solidsto-titratable acid ratio. Polyethylene bags minimized weight loss, and two out of three times, bagged fruit had lower acids after storage than did the control.

$\mathrm{C}$ ommercial peach (Prunus persica) growers in the southeastern United States depend heavily on the early harvest of peaches for their income given their cost of production and postharvest handling. Once later-maturing cultivars become available, decreasing prices weaken the competitive position of Georgia growers in the market. Because of the comparative advantage resulting from climatic conditions, southeastern U.S. growers can supply peaches in late spring, before they mature in northern states. Growers marketing peach fruit emphasize firmness. Consumers consider firmness a predictor of fruit storability and eating quality. In a study of about 200 consumers assessing satisfaction with the quality of California peaches, Bruhn (1995) found that fruit firmness was among the most important characteristics consumers used to judge eating quality.

In this study, a postharvest application of calcium chloride $\left(\mathrm{CaCl}_{2}\right)$ was evaluated as a method for improving peach firmness. $\mathrm{CaCl}_{2}$ is a naturally occurring compound, inexpensive, edible, and approved by the U.S. Food and Drug Administration for preharvest and postharvest use. The quality of many horticultural crops

${ }^{1}$ Poznan Agricultural University, Poznan, Poland.

${ }^{2}$ Department of Agricultural and Applied Economics, University of Georgia, Griffin Campus, 1109 Experiment Street, Griffin, GA, 30223-1791.

${ }^{3}$ Department of Biological and Agricultural Engineering, University of Georgia, Griffin, GA, 30223-1791 ${ }^{4}$ Corresponding author. E-mail: wflorko@griffin. uga.edu. has been improved by increasing the Ca content (Abdalla and Childers, 1973; Bassi et al., 1998; Ferguson, 1984; Robson et al., 1989; Saftner et al., 1999). The most common commercial method of application is one or more preharvest sprays (Bhullar et al., 1981; Brar et al., 1998). Foliar application of $\mathrm{CaCl}_{2}$ at low concentrations (for example, $1.7 \mathrm{~kg} \cdot \mathrm{ha}^{-1}$ $\mathrm{CaCl}_{2}$ per season) was shown to improve late-season peach fruit quality after 4 weeks of storage at $\mathrm{l}^{\circ} \mathrm{C}$ (Robson et al., 1989). Later studies of foliar application of commercial Ca sources at variable rates under growing conditions in California (Crisosto et al., 2000) were ineffective in increasing the $\mathrm{Ca}$ concentration in fruit and showed no effect on firmness of mid and late-season cultivars. A postharvest pressure infiltration of $2 \%$ or $4 \% \mathrm{CaCl}_{2}$ solution into green ripe peaches increased $\mathrm{Ca}$ concentrations in the flesh but caused surface injury (Conway, 1987). Wills and Mahendra (1989) reported that peach fruit treatment through vacuum infiltration with $1 \%$ Ca solution delayed ripening (from 11.1 to 14.4 d) and increased the market life by $30 \%$, but they did not report effects on fruit firmness. However, this method requires special equipment and is impractical for many growers and packers. Prussia et al. (2005) reported the effects of a $2 \% \mathrm{CaCl}_{2}$ solution dip on two early-maturing peach cultivars stored over a 2l-d period and the results indicated improved firmness retention. The current study expands and complements the earlier study by including three cultivars and testing the use of polyethylene bags to store peaches. Recently, Manganaris et al., (2005a) reported that postharvest immersion of nectarines $(P$. persica) in calcium salt solutions led to increased total and cell wall Ca content, tissue firmness, and extended storage life. In the case of canned peaches, Manganaris et al. (2005b) found that fruit prepared for canning covered with a solution containing $\mathrm{CaCl}_{2}$, calcium lactate, or calcium propionate and with adjusted $\mathrm{Ca}$ concentration to $360 \mathrm{mg} \cdot \mathrm{L}^{-1}$ retained firmness better than untreated fruit. The Ca content of treated canned peaches increased more than five times compared to control fruit.

In addition to treating peaches with $\mathrm{Ca}$, we also tested the effects of polyethylene bags as a moisture barrier on the firmness and quality of stored peaches. Under standard industry handling procedures, it is difficult to maintain high relative humidity $(\mathrm{RH})$ during transport and short-term storage. The optimal RH for fresh peaches exceeds 95\% (Whitelock et al., 1994), but the ambient air surrounding fruit after harvest and during grading, packing, and shipping is considerably less. Fresh peaches transpire, leading to measurable weight loss and eventually resulting in the softening of flesh, the loss

\begin{tabular}{llll}
\hline $\begin{array}{l}\text { Units } \\
\text { To convert U.S. to SI, } \\
\text { multiply by }\end{array}$ & U.S. unit & SI unit & $\begin{array}{l}\text { To convert SI to U.S., } \\
\text { multiply by }\end{array}$ \\
\hline 2.54 & inch(es) & $\mathrm{cm}$ & 0.3937 \\
25.4 & inch(es) & $\mathrm{mm}$ & 0.0394 \\
645.1600 & inch & $\mathrm{mm}^{2}$ & 0.0016 \\
1.1209 & $\mathrm{lb} / \mathrm{acre}$ & $\mathrm{kg} \cdot \mathrm{ha}^{-1}$ & 0.8922 \\
4.4482 & $\mathrm{lbf}$ & $\mathrm{N}$ & 0.2248 \\
28.3495 & $\mathrm{oz}$ & $\mathrm{g}$ & 0.0353 \\
28,350 & $\mathrm{oz}$ & $\mathrm{mg}$ & $3.5274 \times 10^{-5}$ \\
1 & $\mathrm{ppm}$ & $\mathrm{mg} \cdot \mathrm{L}^{-1}$ & 1 \\
$\left({ }^{\circ} \mathrm{F}-32\right) \div 1.8$ & ${ }^{\circ} \mathrm{F}$ & ${ }^{\circ} \mathrm{C}$ & $\left(1.8 \times{ }^{\circ} \mathrm{C}\right)+32$
\end{tabular}


of juiciness, and skin shriveling. Weight loss is not unique to peaches; a simple method used to reduce weight loss, for example, in strawberries (Fragaria spp.) and pears (Pyrus spp.) is by packing them in polyethylene bags and placing them in boxes (Paull, 1999; Slaughter et al., 1998). In addition to increasing $\mathrm{RH}$ around the fruit, this inexpensive and practical approach also modifies the atmosphere and reduces the respiration rate (Moyls et al., 1998).

Although peaches may maintain their firmness, attributes important from the eating quality standpoint may be lacking. The delay of maturity in Ca-sprayed fruit can affect the soluble solids content (SSC) and titratable acidity. Therefore, we monitored changes in SSC and titratable acidity throughout the experiment. The maturity-delaying effect of Ca sprays (Raese and Drake, 2000; Tzoutzoukou and Bouranis, 1997) may also delay the change of fruit color. Peach fruit ground color is an important indicator of the maturity stage (Delwiche and Baumgardner, 1983, 1985).

\section{Material and methods}

Peaches of three early-tomidseason-maturing cultivars ('Goldprince', 'Juneprince', and 'Harvester') grown for the fresh market were used for this study.

Fruit Selection. Fruit were obtained from a major grower/ packer located in central Georgia, a primary commercial peach-producing area (Hubbard et al., 1998). All fruit were harvested at commercial maturity according to fruit size and surface background color. Growers consider a peach fruit to be of commercial maturity if it is between $2 \frac{1 / 4}{4}$ inches and $2 \frac{1}{2}$ inches in diameter with the background color matching chip 2 on a scale of six colors. The fruit were hydrocooled to $\approx 4{ }^{\circ} \mathrm{C}$ for $30 \mathrm{~min}$ at the beginning of normal postharvest handling processes at the packinghouse. Fruit were then graded to meet commercial size uniformity and maturity according to the U.S. Department of Agriculture grade "U.S. No. 1." Only "U.S. No. I" fruit were evaluated. Experiments with fruit from each cultivar were conducted using peaches harvested at the beginning ('Goldprince', 22 May 2001; 'Juneprince', 29 May;
'Harvester', 12 June), in the middle ('Goldprince', 25 May; 'Juneprince', 2 June; 'Harvester', 15 June), and at the end of the harvest period ('Goldprince', 29 May; 'Juneprince', 6 June; 'Harvester', 18 June), which typically lasts from 7 to $11 \mathrm{~d}$ for each cultivar. The three harvests coincided with the commercial harvest of each cultivar in central Georgia. The duration of each storage period was $14 \mathrm{~d}$ (i.e., a period comparable to the length of time it takes to pack, ship, and retail peaches originating in the southeastern United States).

At each harvest date, several boxes of graded peaches of the tested cultivars were randomly selected as they were leaving the packing line and were transferred to the University of Georgia laboratory located about a l-h drive away. A total of 408 peaches of each cultivar and harvest date were chosen, and each fruit was marked with a code number to facilitate recording of test results and measurements. For nondestructive tests, 40 fruit were collected at each of their harvests to give 10 replicates (fruit per replicate unless otherwise noted) per treatment. Nondestructive evaluations occurred at harvest and at four other times during storage. Another 288 fruit were assigned for the destructive test conducted four times on six replicates for each of four treatments at three harvest dates. The first measurement was performed on two samples of six fruit with and without the dip for each of the three harvest dates.

FrUit HANDLING AND STORAGE CONDITIONS. After fruit selection and initial evaluation of external color, firmness, weight, titratable acidity, and SSC, the two $\mathrm{CaCl}_{2}$ treatments (10 fruit each for the nondestructive tests and six fruit for each destructive test) half the fruit were submerged for $30 \mathrm{~min}$ in $2 \%(\mathrm{w} / \mathrm{v}) \mathrm{CaCl}_{2}$ solution at room temperature $\left(\approx 20^{\circ} \mathrm{C}\right)$. Peaches were then placed in a single layer and dried with a fan within $30 \mathrm{~min}$. The $\mathrm{CaCl}_{2}$-treated fruit and fruit not dipped in the solution were then each divided into two subsamples. Plastic containers $(15.9 \mathrm{~cm}$ high $\times 28.6 \mathrm{~cm}$ wide $\times 30.5 \mathrm{~cm}$ long) with open tops held one subsample of $\mathrm{Ca}$-treated and one subsample of control fruit, and the boxes were covered with polyethylene bags $(0.04 \mathrm{~mm}$ thick) to maintain RH above $95 \%$. The remaining treated and control fruit were boxed and stored without bags. All fruit were stored at $4{ }^{\circ} \mathrm{C}$ with $85 \%$ $\mathrm{RH}$. The RH was measured in representative bags and in storage rooms using a probe (model HMP35C; Campbell Scientific, Logan, UT) with a capacitive RH sensor (Vaisala, Woburn, MA) with a range from $0 \%$ to $100 \% \mathrm{RH}$ and with an accuracy of $\pm 3 \% \mathrm{RH}$ in the $90 \%$ to $100 \% \mathrm{RH}$ range $( \pm 2 \% \mathrm{RH}$ from $0 \%$ to $90 \% \mathrm{RH})$.

The peach fruit were exposed to ambient temperatures for $\approx 6 \mathrm{~h}$ after hydrocooling, until placement in the storage chambers at the laboratory. All peaches were stored at $4{ }^{\circ} \mathrm{C}$. Each fruit was weighed using a laboratory balance with an accuracy of $0.1 \mathrm{~g}$ (Ohaus I-20W, model B25AS; Ohaus, Florham Park, NJ). Firmness and quality evaluations were carried out during the subsequent 14-d storage period by means of destructive and nondestructive tests. Fruit were evaluated individually.

Firmness. Firmness was evaluated nondestructively by a panel of three independent judges experienced in postharvest texture evaluation. Evaluations were recorded on a 9 -point scale. Evaluations of individual panel members were averaged. The descriptive scale was: $l=$ too soft fruit, skin bowing under its weight; $2=$ very soft, easy to damage; $3=$ soft; $4=$ medium soft, eating softness; $5=$ medium soft; $6=$ selling softness; $7=$ hard; $8=$ very hard; $9=$ very hard, very difficult to dent by finger. Nondestructive test results are averages of 90 measurements of one measurement per fruit for each judge.

Fruit firmness was also measured destructively using a Magness-Taylor $(\mathrm{M}-\mathrm{T})$ fruit penetrometer tester (FT Fruit-Tester, formerly known as EFFEGI) mounted in a drill press to control the movement (model FT011; Facchini Francesco Srl, Brescia, Italy). The M-T test was conducted with a 7.9-mm-diameter $\mathrm{M}$-T probe $\left(49 \mathrm{~mm}^{2}\right)$ on whole fruit with a small area of the skin removed. The maximum penetration force to the depth of $10 \mathrm{~mm}$ was registered as the $\mathrm{M}-\mathrm{T}$ firmness with kilograms of force $(0.1 \mathrm{~kg}$ accuracy) converted to Newtons. The firmness of each fruit was measured on opposite sides of the equator to give two readings per fruit. Results from destructive tests are means of 30 recordings (i.e., scores assigned by 
all judges evaluating all fruit in the sample in two readings).

Color Measurement. The ground color is defined as the greenyellow coloration of the peach skin exclusive of the red-pigmented area. Peach industry graders commonly compare the ground color with painted color charts. The evaluation of background surface color was carried out on the nonblushed side of each fruit and was compared with a commercial color chart containing six color stages (Delwiche and Baumgardner, 1983). Color chip 1 is green (least mature), and the subsequent chips progress to 6 , which is dark yellow (very mature). The color was evaluated by a panel of three judges. Each judge evaluated all fruit from the control and treatment samples. The measurements were averaged for each date that the test was performed during the 14-d storage period.

SOLUBLE SOLIDS AND TITRATABLE ACIDITY. On the day of harvest and on the last day of the 14-d storage period, a sample of juice was obtained from six replicates. The SSC of the juice extracted from the whole fruit was measured with a hand-held temperature-compensated refractometer (model \#10431; American Optical, Buffalo, NY) with a scale reading from 0 to $50{ }^{\circ}$ Brix $(0 \%-50 \%$ SSC $)$ with a resolution of $0.25^{\circ} \mathrm{Brix}(0.25 \%$ SSC). Two measurements of SSC from the same juice sample were recorded for each fruit and were averaged. Titratable acidity (TA) was determined by titrating a $1-\mathrm{mL}$ sample with $0.1 \mathrm{~N}$ sodium hydroxide to an endpoint of $\mathrm{pH} 8.2$ using an Accumet $\mathrm{pH}$ meter (Fisher Scientific, Pittsburgh), and an automatic burette. The TA in malic acid equivalents in milligrams per liter was assessed using juice from each fruit. Results from testing two juice samples per fruit were recorded and averaged. The SSC and TA were determined by averaging three replications of six fruit at the beginning and end of the storage period. The measurements from the three sets of six replicates represented fruit gathered at three harvest dates for each cultivar.

Individual fruit measurements were summed and averaged for each day when they were evaluated. Average values from firmness tests, soluble solids, acidity, color, weight loss,
SSC:TA measurements, and decay evaluation were tested for statistical differences using Duncan's multiple range test. The mean separation test was applied to measurements collected on each day from the three treatments and control. The tested measurements were averages obtained for fruit collected at three harvest dates for each cultivar. As such, comparisons focus on a single cultivar and compare the treatments on a specific day during the storage experiment.

\section{Results and discussion}

Softening of stored peaches evaluated by the sensory and instrumental methods showed significant differences in firmness among four selected treatments (Table 1). In all cultivars, statistically detectable significant differences appeared on the third day of the 14-d storage period and progressed throughout the remaining storage period, although the rate of firmness change varied across cultivars depending on cultivar. Dipping in a $\mathrm{CaCl}_{2}$ solution slowed the loss of firmness compared with the control, especially in the two earliest-maturing cultivars.

Nondestructive firmness-testing devices have not been commonly used in peach packinghouses because of the relatively slow speed of measurement (Hung et al., 2001) and the implied relatively high cost resulting from delayed sorting and grading. In most commercial packinghouses, firmness is evaluated by humans, and this study also used humans for nondestructive firmness evaluations. Using a 9-point scale, sensory firmness measurements of 'Goldprince' declined steadily, and after $14 \mathrm{~d}$ of storage, ranged from a loss of 0.9 points $(12.9 \%$ reduction from the level record on day 0 of the storage period) in treatments involving the combination of the $\mathrm{CaCl}_{2}$ dip and polyethylene bags as a moisture barrier, to a loss of 2.3 points $(31.9 \%)$ for the control treatment. The loss of sensory firmness was even greater in 'Juneprince'. After $14 \mathrm{~d}$ of storage, firmness scores declined by 1.6 points (21.1\% from the level recorded on day 0 ) in fruit dipped in $\mathrm{CaCl}_{2}$, boxed, and placed inside polyethylene bags, but in the control fruit, the decline from the initial firmness was $41 \%$. After storage, 'Juneprince' firmness was slightly less than that of 'Goldprince', although the initial firmness was more pronounced and greater in 'Juneprince' firmness than in 'Goldprince'. For 'Harvester', the firmness loss after storage was least in fruit dipped in the $\mathrm{CaCl}_{2}$ solution and then placed inside polyethylene bagsloosing only 1.1 points (13.4\%) of their initial firmness. Control fruit lost 2 points (24.4\%) from their initial scores.

Control fruit softened steadily, as indicated by results of sensory and instrumental firmness measures (Table 1), but at different rates for all cultivars. Fruit subjected to the $\mathrm{CaCl}_{2}$ dip and stored in boxes with bags consistently retained a higher level of firmness than did control fruit. The effect of using bags strengthened the effects of $\mathrm{CaCl}_{2}$ on fruit firmness. Also, fruit stored in boxes covered with bags, but not dipped in the $\mathrm{CaCl}_{2}$, scored higher in sensory firmness tests than control fruit after storage. All Ca-treated peaches stored unprotected from the loss of moisture maintained a relatively high firmness level compared with the control except for 'Harvester' after $14 \mathrm{~d}$ of storage and instrumental measurements.

Results of the destructive test were consistent with the nondestructive firmness test. Earlier studies comparing the performance of several destructive devices, e.g., Effegi, MT, Instron-held MT probe (Abbott et al., 1976; Giese, 1995), and nondestructive tools, e.g., laser puff-detector or near-infrared spectroscopy (Fan et al., 1994; Hung et al., 1999; Ortiz et al., 2001), showed a correlation of results between destructive and nondestructive tests. The MT penetrometer showed the loss of firmness progressing faster for control fruit than for the other treatments, with the exception of $\mathrm{CaCl}_{2}$-dipped 'Harvester' not placed in bags, where the fruit was marginally softer than the control fruit, but the difference was statistically insignificant. At the end of the 14-d storage period, the difference between any of the treatments and the control sample ranged from 4 to $10.8 \mathrm{~N}$ for 'Goldprince', from 2.0 to $7.8 \mathrm{~N}$ for 'Juneprince', and from -1.0 to $2.9 \mathrm{~N}$ for 'Harvester' (Table $\mathrm{l}$ ).

The instrumental firmness of 'Juneprince' and 'Harvester' with bags usually did not differ significantly 


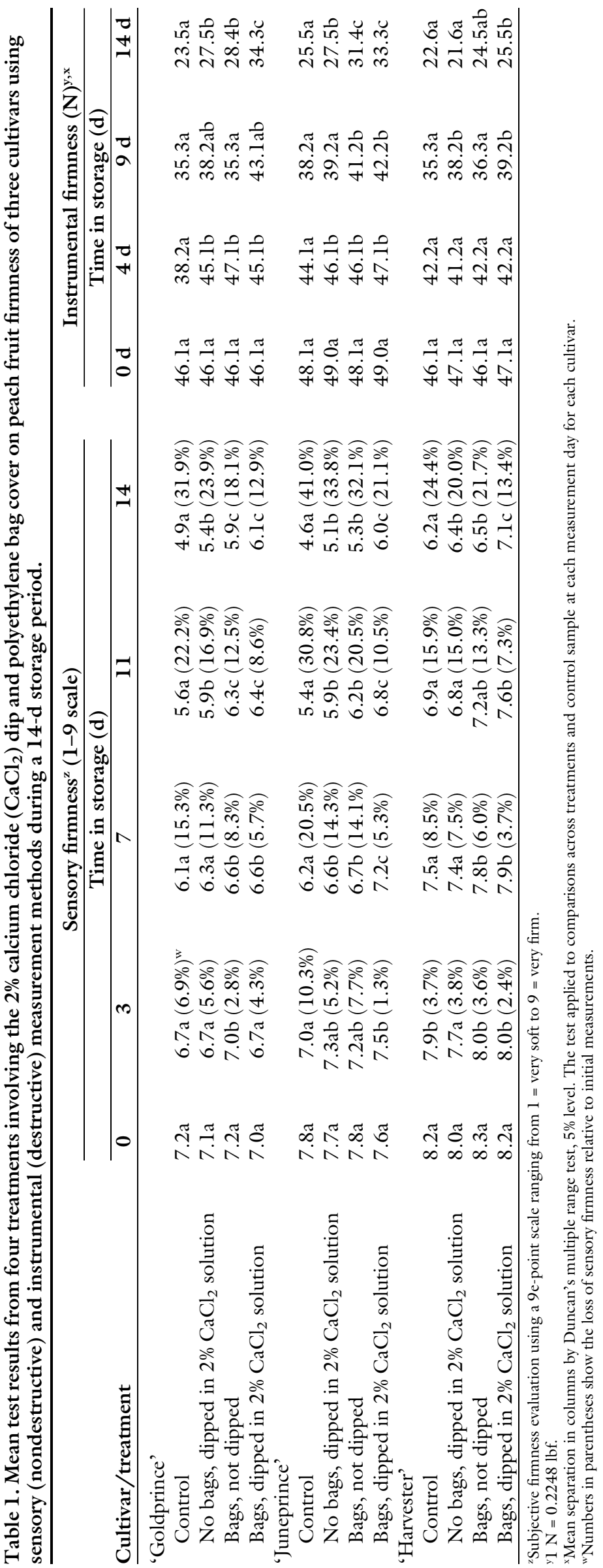

between samples dipped or not dipped in the $2 \% \mathrm{CaCl}_{2}$ solution (Table 1), but the percentage loss of sensory firmness tended to decline more slowly for the dipped fruit. The delay of softening of 'Goldprince' was more pronounced for the dipped fruit in case of sensory and instrumental firmness. The differences were statistically confirmed for sensory firmness after $7 \mathrm{~d}$ of storage. Combining $\mathrm{CaCl}_{2}$ dips with bagging tended to reduce softening the most during storage.

The levels of SSC reported here generally agreed with those reported by Karakurt et al. (2000) for meltingflesh cultivars except for 'Harvester', which had lower SSC than 'Juneprince' and 'Goldprince' (Table 2). SSC was the lowest for fruit of 'Goldprince' and 'Harvester' covered with polyethylene bags but not dipped in the $\mathrm{CaCl}_{2}$ solution. It was also the lowest together with control fruit in case of 'Juneprince'. Dipped fruit had a greater loss of SSC than did the control fruit in the case of 'Harvester', according to the test results (Table 2). It appears that the application of a $\mathrm{CaCl}_{2}$ dip to 'Goldprince' and 'Juneprince' had a particularly desirable effect because it generally enhanced the content of soluble solids. It is possible that the control fruit used energy for respiration, whereas the dipped fruit benefited from $\mathrm{Ca}$, which is a known respiration inhibitor. On the other hand, mean separation test results did not detect these significant differences at the beginning of the storage period, but confirmed differences at the end of storage, possibly from water loss.

In general, the TA of all fruit for the three cultivars declined (Table 2). Specific treatments had a mixed effect on TA. After 2 weeks of storage, there was no difference between 'Goldprince' and dipped fruit, but fruit placed in bags had decreased TA. With 'Juneprince', significant differences are apparent within treated fruit, and between treated fruit and control. With 'Harvester', there were no differences among treated fruit and the control.

The SSC:TA ratio indicated that the fruit ripeness increased during storage for fruit that was dipped in the solution or wrapped in bags with the exception of the 'Goldprince' that were only covered with polyethylene bags. The highest ratio was obtained 
Table 2. Mean test results for soluble solid content (SSC), titratable acidity (TA), SSC:TA ratio, color, and weight for peach fruit of three cultivars on the first and the last day of the 14 -d storage period after the $2 \%$ calcium chloride dip at $\approx 20{ }^{\circ} \mathrm{C}$ $\left(68.0{ }^{\circ} \mathrm{F}\right)$ for $30 \mathrm{~min}$ and the use of polyethylene bags cover on boxes. ${ }^{\mathrm{z}}$

\begin{tabular}{|c|c|c|c|c|c|c|c|c|c|c|}
\hline \multirow{2}{*}{ Cultivar/treatment } & \multicolumn{2}{|c|}{$\begin{array}{c}\text { SSC } \\
(\%)\end{array}$} & \multicolumn{2}{|c|}{ TA mg malic } & \multicolumn{2}{|c|}{$\begin{array}{l}\text { SSC:TA } \\
\text { ratio }\end{array}$} & \multicolumn{2}{|c|}{$\begin{array}{c}\text { Color } \\
(1-6 \text { scale })^{x}\end{array}$} & \multicolumn{2}{|c|}{$\begin{array}{c}\text { Wt loss } \\
\text { (\% initial wt) }\end{array}$} \\
\hline & \multicolumn{2}{|c|}{$\begin{array}{l}\text { Time in } \\
\text { storage }\end{array}$} & \multicolumn{2}{|c|}{$\begin{array}{l}\text { Time in } \\
\text { storage }\end{array}$} & \multicolumn{2}{|c|}{$\begin{array}{l}\text { Time in } \\
\text { storage }\end{array}$} & \multicolumn{2}{|c|}{$\begin{array}{l}\text { Time in } \\
\text { storage }\end{array}$} & \multicolumn{2}{|c|}{$\begin{array}{l}\text { Time in } \\
\text { storage }\end{array}$} \\
\hline \multicolumn{11}{|l|}{ 'Goldprince' } \\
\hline Control & $10.6 \mathrm{a}$ & $10.5 b$ & $1.24 \mathrm{a}$ & $0.84 b$ & $8.55 a$ & $12.50 \mathrm{a}$ & $1.8 \mathrm{ab}$ & $3.2 \mathrm{a}$ & $7.3 b$ & $9.8 \mathrm{~b}$ \\
\hline Bags, dipped & $10.8 \mathrm{a}$ & $10.3 \mathrm{~b}$ & $1.25 \mathrm{a}$ & $0.75 a$ & $8.64 \mathrm{a}$ & $13.73 b$ & $1.9 \mathrm{~b}$ & $3.0 \mathrm{a}$ & $0.9 \mathrm{a}$ & $1.2 \mathrm{a}$ \\
\hline \multicolumn{11}{|l|}{ 'Juneprince' } \\
\hline Control & $10.7 \mathrm{a}$ & $10.2 \mathrm{a}$ & $1.07 \mathrm{a}$ & $0.91 \mathrm{c}$ & $10.0 \mathrm{a}$ & $11.21 \mathrm{a}$ & $1.6 \mathrm{~b}$ & $3.4 b$ & $6.6 b$ & $8.4 b$ \\
\hline No bags, dipped & $10.5 \mathrm{a}$ & $11.0 \mathrm{~b}$ & $1.09 \mathrm{a}$ & $0.82 b$ & $9.63 a$ & $13.41 \mathrm{~b}$ & $1.7 \mathrm{~b}$ & $3.0 \mathrm{ab}$ & $7.7 \mathrm{c}$ & $9.7 b$ \\
\hline Bags, not dipped & $10.6 \mathrm{a}$ & $10.3 \mathrm{a}$ & $1.07 \mathrm{a}$ & $0.78 \mathrm{a}$ & $9.91 \mathrm{a}$ & $13.21 b$ & $1.5 \mathrm{a}$ & $2.8 \mathrm{ab}$ & $1.0 \mathrm{a}$ & $1.2 \mathrm{a}$ \\
\hline Bags, not dipped & $9.4 \mathrm{a}$ & $8.8 \mathrm{a}$ & $0.92 \mathrm{a}$ & $0.70 \mathrm{a}$ & $10.22 \mathrm{a}$ & $12.57 \mathrm{~b}$ & $1.4 \mathrm{a}$ & $2.4 \mathrm{a}$ & $0.5 \mathrm{a}$ & $0.6 \mathrm{a}$ \\
\hline Bags, dipped & $9.5 \mathrm{a}$ & $9.0 \mathrm{a}$ & $0.94 \mathrm{a}$ & $0.75 a$ & $10.11 \mathrm{a}$ & $12.00 \mathrm{~b}$ & $1.4 \mathrm{a}$ & $2.2 \mathrm{a}$ & $1.2 \mathrm{~b}$ & $1.3 \mathrm{a}$ \\
\hline
\end{tabular}

${ }^{2}$ Mean separation in columns by Duncan's multiple range test, $5 \%$ level. The test applied to comparisons across treatments and control sample at each measurement day for each cultivar.

${ }^{y}$ Malic acid in $\mathrm{mg} ; \mathrm{l} \mathrm{mg}=3.5274 \times 10^{-5} \mathrm{oz}$

${ }^{x}$ Measured using the six-step commercial color chart, where $1=$ least mature, green and 6 = very mature, dark yellow.

for 'Juneprince' after $14 \mathrm{~d}$ of storage. Fruit ripened as expected for all treatments.

Color changes. In general, color changes in fruit of all treatments and the control sample were substantial during the 2 -week storage (Table $2)$. Although peaches were harvested at commercial maturity by a commercial grower, their color score consistently improved. However, differences in color between treatments were much less pronounced. Negligible color changes observed among treatments on 'Goldprince' were statistically insignificant. Color changes were pronounced among treatments for 'Juneprince, but according to the test, three treatments fell into the same category, suggesting a clear difference only between the control sample and peaches dipped in the $\mathrm{CaCl}_{2}$ solution and stored under polyethylene bags. 'Harvester' showed significant differences in color development between the control and the three treatments, which all were lower than the control. Color scores tended to be lowest in fruit dipped in the $\mathrm{CaCl}_{2}$ solutions.

The results of color tests complement the observations of Génard et al. (1994), who did not find a correlation between firmness and color at harvest in comparison across cultivars. Differences in color scores for the various treatments were seldom confirmed by statistical analysis in contrast to firmness-test results obtained from the destructive and nondestructive experiments. The data show (Tables 1 and 2 ) a weak negative relationship between firmness and color changes, although Delwiche and Baumgardner (1983) and Brown and Walker (1990) reported a strong correlation between color and firmness due to maturation.

Weight Loss. Maintaining a high $\mathrm{RH}$ proved beneficial by reducing the weight loss by several percentage points (Table 2). The differences between the control fruit and fruit in bags suggest potentially substantial benefits from the use of this simple method. The gains were particularly large for the two earliest-maturing cultivars, 'Goldprince' and 'Juneprince'. The greatest benefit occurred within the first $7 \mathrm{~d}$ of storage. During the second half of the storage period, the gains increased, but at a lower rate. The exception was 'Harvester' treated with the $\mathrm{CaCl}_{2}$ solution. It is possible that the rate of respiration varied across cultivars and stabilized faster for some cultivars than for others.

'Goldprince' not protected by the moisture-maintaining barrier lost $10.6 \%$ of its initial weight (average of control and no bag/dipped treatment) compared with fruit stored in polyethylene bags, which lost $1.0 \%$ of their initial weight. For 'Juneprince' and 'Harvester, the differences in weight loss between treatments with and without polyethylene bags ranged from $1.2 \%$ to $9.1 \%$ and from $0.9 \%$ to $5.8 \%$, respectively.

Decay. The percentage of decayed fruit increased during storage to generally less than $7 \%$ after $7 \mathrm{~d}$, and $6 \%$ after $14 \mathrm{~d}$. There were no significant differences between cultivars or treatments.

\section{Conclusion}

Dipping peaches in a $2 \% \mathrm{CaCl}_{2}$ solution improved firmness and largely maintained the SSC, while increasing the SSC:TA ratio. $\mathrm{RH}$ should be increased throughout the whole storage chain. By using the polyethylene bags in boxed fruit, weight loss was minimized. From a practical standpoint, these experiments have potentially important implications because the dip and the use of bags is inexpensive, can be easily adopted by packinghouses, and uses substances or methods approved for use in food production and distribution. For example, the addition of $\mathrm{CaCl}_{2}$ during hydrocooling is feasible and will not disrupt currently used commercial 
practices. The time required to hydrocool fruit in central Georgia is comparable with the length of dips applied in this study. The cost of the $2 \% \mathrm{CaCl}_{2}$ solution used in the reported experiments is very small. Additional tests may be conducted to ensure a similar effect despite the differences in the solution temperatures.

However, future research is needed to determine the optimum concentrations for postharvest dips. Although other fruit are treated with $\mathrm{CaCl}_{2}$ sprays, the spray concentration varies. Several commercially available mixes for $\mathrm{CaCl}_{2}$ dips or sprays are available, but their use on peach fruit requires additional research.

\section{Literature cited}

Abbott, J.A., A.E. Watada, and A.R. Massie. 1976. Effegi, Magness-Taylor, and Instron fruit pressure testing devices for apples, peaches, and nectarines. J. Amer. Soc. Hort. Sci. 101:698-700.

Abdalla, D.A. and N.F. Childers. 1973. Calcium nutrition of peach and prune relative to growth, fruiting, and fruit quality. J. Amer. Soc. Hort. Sci. 98:517522.

Bassi, D., I. Mignani, and M. Rizzo. 1998. Calcium and pectin influence peach flesh texture. Acta Hort. 465:433-438.

Bhullar, J.S., B.S. Dhillon, and J.S. Randhawa. 1981. Effect on pre-harvest calcium nitrate sprays on the ambient storage of Flordasun peach fruits. J. Res. Punjab Agr. Univ. 18:282-286.

Brar, S.S., S.S.A. Simmani, and W.S. Dhillon. 1998. Effect of calcium nitrate and hydro-cooling on cold storage life of peach cv. Shan-I-Punjab. J. Food Sci. Technol. 35(3):223-226.

Brown, G.S. and T.D. Walker. 1990. Indicators of maturity in apricots using biplot multivariate analysis. J. Sci. Food Agr. 53(3):321-331.

Bruhn, C.M. 1995. Consumer and retailer satisfaction with the quality and size of California peaches and nectarines. J. Food Qual. 18(3):241-256.

Conway, W. 1987. Effects of preharvest and postharvest calcium treatments of peaches on decay caused by Monolinia fructicola. Plant Dis. 71:1084-1086.
Crisosto, C.H., K.R. Day, R.S. Johnson, and D. Garner. 2000. Influence of inseason foliar calcium sprays on fruit quality and surface discoloration incidence of peaches and nectarines. J. Amer. Pomol. Soc. 54(3):118-122.

Delwiche, M.J. and R.A. Baumgardner. 1983. Ground color measurements of peach. J. Amer. Soc. Hort. Sci. 108: 1012-1016.

Delwiche, M.J. and R.A. Baumgardner. 1985. Ground color as a peach maturity index. J. Amer. Soc. Hort. Sci. 1 10:53-57.

Fan, S., S.E. Prussia, and Y.C. Hung. 1994. Evaluating the UGA laser-puff food firmness detector. Proc. Intl. Winter Meeting Amer. Soc. Agr. Eng., Atlanta, GA. 13-16 Dec. p. 24. (Abstr.).

Ferguson, I.B. 1984. Calcium in plant senescence and fruit ripening. Plant Cell Environ. 7(6):477-489.

Génard, M., M. Souty, S. Holmes, M. Reich, and L. Breuils. 1994. Correlations among quality parameters of peach fruit. J. Sci. Food Agr. 66:241-245.

Giese, J. 1995. Measuring physical properties of foods. Food Technol. 49(2):54$56,58,60-63$.

Hubbard, E.E., W.J. Florkowski, T. Park, and H. Witt. 1998. Commercial peach tree inventory and prospectus, Georgia 1995. Univ. Georgia, College Agr. Environ. Sci., Georgia Agr. Expt. Sta., Res. Rept. 650.

Hung, Y.-C., S.E. Prussia, and G.O.I Ezeike. 1999. Nondestructive firmness sensing using a laser air-puff detector. Postharvest Biol. Technol. 16:15-25.

Hung, Y.-C., S.E. Prussia, and G.O.I. Ezeike. 2001. Firmness measurement methods, p. 243-285. In: S. Gunasekaran (ed.). Nondestructive food evaluation. Marcel Dekker, New York.

Karakurt, Y., D.J. Huber, and W.B. Sherman. 2000. Development of off-flavour in non-melting flesh peach genotypes. J. Sci. Food. Agr. 80:1841-1847.

Manganaris, G.A., M. Vasilakakis, G. Diamantidis, and I. Mignani. 2005a. Effect of post-harvest calcium treatments on the physicochemical properties of cell wall pectin in nectarine fruit during ripening after harvest or cold storage. J. Hort. Sci. Biotechnol. 80(5):611-617.

Manganaris, G.A., M. Vasilakakis, G. Diamantidis, and I. Mignani. 2005b. Effects of calcium additives on physicochemical aspects of cell wall pectin and sensory attributes of canned peach (Prunus persica (L.) Batsch cv Andross). J. Sci. Food Agr. 85:1773-1778.

Moyls, A.L., D.L. McKenzie, R.P. Hocking, P.M.A. Toivonen, P. Delaquis, B. Girard, G. Ortiz, C, P. Barreiro, E. Correa, F. Riquelme, and M. Ruiz-Altisent. 2001. Non-destructive identification of wooly peaches using impact response and near-infrared spectroscopy. J. Agr. Eng. Res. 78(3):281-289.

Paull, R.E. 1999. Effect of temperature and relative humidity on fresh commodity quality. Postharvest Biol. Technol. 15:263-277.

Prussia, S.E., D. Aggarwal, G.P. Lysiak, and W.J. Florkowski. 2005. Postharvest calcium chloride dips for increasing peach firmness. Acta Hort. 682:15511557.

Raese, J.T. and S.R. Drake. 2000. Effect of calcium sprays, time of harvest, cold storage, and ripeness on fruit quality of 'Anjou' pears. J. Plant Nutr. 23(6): 843-853.

Robson, M.G., J. Hopfinger, and P. Eck. 1989. Postharvest sensory evaluation of calcium treated peach fruit. Acta Hort. 254:173-177.

Saftner, R.A., W.S. Conway, and C.E. Sams. 1999. Postharvest calcium infiltration alone and combined with surface coating treatments influence volatile levels, respiration, ethylene production, and internal atmospheres of Golden Delicious apples. J. Amer. Soc. Hort. Sci. 124: 553-558.

Slaughter, D.C., J.F. Thompson, and R.T. Hinsch. 1998. Packaging Bartlett pears in polyethylene film bags to reduce vibration injury in transit. Trans. Amer. Soc. Agr. Eng. 41(1):107-114.

Tzoutzoukou, C.G. and D.L. Bouranis. 1997. Effect of preharvest application of calcium on the postharvest physiology of apricot fruit. J. Plant Nutr. 20(2/3): 295-309.

Whitelock, D.P., G.H. Brusewitz, M.W. Smith, and Z. Xihai. 1994. Humidity and airflow during storage affect peach quality. HortScience 29:798-801.

Wills, R.B.H. and M.S. Mahendra. 1989. Effect of postharvest application of calcium on ripening of peach. Austral. J. Expt. Agr. 29:751-753. 